\title{
Analisis Aplikasi Marbel Huruf Versi Mobile Terhadap Pembelajaran Membaca di Desa Semanding Ponorogo
}

Marbel Letter Application of Mobile Version Analysis to Reading Learning in Semanding Ponorogo Village

\author{
${ }^{1}$ Jamilah Karaman, ${ }^{2}$ Arief Setyanto, ${ }^{3}$ Amir Fatah Sofyan \\ ${ }^{1,2,3}$ Magister Teknik Informatika, Universitas Amikom Yogyakarta \\ 1,2,3 Yogyakarta, Indonesia
}

E-mail: ${ }^{1}$ milafergie.mf@gmail.com, ${ }^{2}$ arief_s@amikom.ac.id, ${ }^{3}$ amir@amikom.ac.id

Abstrak - Perkembangan teknologi khususnya teknologi informasi dan komunikasi banyak menawarkan berbagai kemudahan-kemudahan dalam pembelajaran, yang memungkinkan terjadinya pergeseran orientasi pembelajaran dari proses penyajian berbagai pengetahuan menjadi proses bimbingan dalam melakukan eksplorasi individual terhadap ilmu pengetahuan. Media pembelajaran interaktif untuk anak yang marak saat ini adalah pedia pembelajaran berbasis game yaitu "MARBEL". Marbel ini merupakan singkatan dari "Mari Belajar", aplikasi marbel merupakan aplikasi pendidikan (mobile learning) untuk anak-anak berusia 2 sampai dengan 8 tahun sehingga dibuatnya aplikasi berbasis mobile bertujuan untuk dapat memudahkan anak dalam proses pembelajarannya.

Kata Kunci-Mobile Learning, Teknologi Pendidikan, Marbel

Abstract - The development of technology, especially information and communication technology offers many ease-ease in learning, which allows the shift of learning orientation from the process of presenting various knowledge into the process of guidance in individual exploration of science. Interactive learning media for children who rampant today is a game-based learning pedia is "MARBEL". Marbel is an abbreviation of "Let's Learn", marbel application is an educational application (mobile learning) for children aged 2 to 8 years so that made mobile-based applications aims to facilitate children in the learning process.

Keywords-Mobile Learning, Educational Technology, Marbel 
INTENSIF, Vol.2 No.2 August 2018

ISSN: 2580-409X (Print) / 2549-6824 (Online)

Website: http://ojs.unpkediri.ac.id/index.php/intensif

\section{PENDAHULUAN}

Perkembangan teknologi pendidikan tidak dapat dilepaskan dengan perkembangan teknologi pada umumnya. Berbagai perangkat pendidikan dan saran pendidikan yang modern turut mendukung optimalisasi proses pembelajaran, baik ditingkat sekolah maupun dalam kehidupan sehari-hari. Mobile learning merupakan model pembelajaran yang memanfaatkan teknologi informasi dan komunikasi. Pada konsep pembelajaran tersebut mobile learning membawa manfaat ketersediaan materi ajar yang dapat di akses setiap saat dan visualisasi materi yang menarik. Hal penting yang perlu di perhatikan bahwa tidak setiap materi pengajaran cocok memanfaatkan mobile learning [1]

Berdasarkan studi pendahuluan yang dilakukan peneliti di wilayah penelitian Desa Semanding Kecamatan Kauman Kabupaten Ponorogo Provinsi Jawa Timur, aplikasi marbel merupakan aplikasi yang marak digunakan oleh orang tua di wilayah tersebut guna melatih dan membantu dalam meningkatkan pengetahuan anak tentang pengenalan huruf, pengenalan angka, pembelajaran menulis, membaca, pengajaran sholat dan pengajaran mengaji. Menurut penuturan banyak orang tua, aplikasi marbel dianggap dapat memudahkan anak dalam proses pembelajarannya sebagai sarana alternatif dalam melakukan pembelajaran berbasis teknologi.

\section{METODE PENELITIAN}

Pada penelitian ini yang digunakan adalah metode kuantitatif. Menurut Sugiono (2008), metode kuantitatif adalah pendekatan ilmiah yang memandang suatu realitas itu dapat diklasifikasikan, konkrit, teramati dan terukur, hubungan variabelnya bersifat sebab akibat dimana data penelitiannya berupa angka-angka dan analisisnya menggunakan statistik. Pendekatan analisis kuantitatif terdiri atas perumusan masalah, menyusun model, mendapatkan data, mencari solusi, menguji solusi, menganalisis hasil, dan menginterprestasikan hasil[2].

Metode analisis data yang digunakan dalam penelitian ini adalah metode Analisis korelasional. Penelitian korelasi atau korelasional adalah suatu penelitian untuk mengetahui hubungan dan tingkat hubungan antara dua variabel atau lebih tanpa ada upaya untuk mempengaruhi variabel tersebut sehingga tidak terdapat manipulasi variable [3].

Rancangan penelitian yang digunakan adalah cross sectional yaitu jenis penelitian yang menekankan pada waktu pengukuran/observasi data variabel independen dan dependen hanya satu kali pada satu saat [4] 
INTENSIF, Vol.2 No.2 August 2018

ISSN: 2580-409X (Print) / 2549-6824 (Online)

Website: http://ojs.unpkediri.ac.id/index.php/intensif

A. Metode Pengumpulan Data

Populasi adalah keseluruhan objek penelitian. Apabila seseorang ingin meneliti semua elemen yang ada dalam wilayah penelitian, maka penelitiannya merupakan penelitian populasi [5] Populasi adalah subyek (misalnya manusia: klien) yang memiliki kriteria yang telah ditetapkan [6]Dalam penelitian ini populasinya adalah anak usia 6-8 Tahun di Desa Semanding Kecamatan Kauman Kabupaten Ponorogo yang menggunakan aplikasi Marbel dengan jumlah 50 responden.

Sampel adalah terdiri dari bagian populasi terjangkau yang dapat dipergunakan sebagai subyek penelitian melalui sampling [6]. Sampel penelitian ini adalah anak usia 6-8 Tahun di Desa Semanding Kecamatan Kauman Kabupaten Ponorogo yang menggunakan aplikasi Marbel dengan jumlah 50 responden.

Teknik pengambilan sampel dalam penelitian ini adalah total sampling. Total sampling adalah teknik pengambilan sampel dimana jumlah sampel sama dengan populasi [7]Alasan mengambil total sampling karena menurut Sugiyono [7], jumlah populasi yang kurang dari 100 seluruh populasi dijadikan sampel penelitian semuanya.

B. Instrumen Penelitian

Pengumpulan data dilakukan dengan menggunakan kuesioner yaitu suatu metode pengumpulan data dengan menyebarkan daftar pertanyaan kepada anak dengan usia 6-8 Tahun yang menggunakan aplikasi Marbel versi Mobile di kabupaten Ponorogo.

Pengukuran kuesioner (usability) menurut pandangan human computer interaction (HCI) yang meliputi Learnability, Efficiency, Memorability, Errors, Satisfaction menggunakan skala Likert dengan kriteria skor pertanyaan sebagai berikut:

Untuk pernyatan positif :

$\begin{array}{ll}\text { SS : Sangat Setuju } & \text { : Skor } 4 \\ \text { S : Setuju } & \text { : Skor } 3 \\ \text { TS : Tidak Setuju } & \text { : Skor } 2 \\ \text { STS : Sangat Tidak Setuju } & \text { : Skor 1 } \\ \text { Untuk pernyataan negatif : } & \\ \text { STS : Sangat tidak setuju } & \text { : Skor } 4 \\ \text { TS : Tidak setuju } & \text { : Skor } 3 \\ \text { S : Setuju } & \text { : Skor 2 } \\ \text { SS : Sangat Setuju } & : \text { Skor 1 }\end{array}$

Pengukuran di deskripsikan pada tabel 1.

100 INTENSIF: Jurnal Ilmiah Penelitian dan Penerapan Teknologi Sistem Informasi 
INTENSIF, Vol.2 No.2 August 2018

ISSN: 2580-409X (Print) / 2549-6824 (Online)

Website: http://ojs.unpkediri.ac.id/index.php/intensif

Tabel 1. PENGUKURAN KUESIONER

\begin{tabular}{|c|c|c|c|c|}
\hline \multirow{2}{*}{ No } & \multirow{2}{*}{ Pernyataan } & \multicolumn{3}{|c|}{ Jawaban } \\
\hline & & SS & $\mathrm{S} \quad \mathrm{TS}$ & STS \\
\hline \multicolumn{5}{|c|}{ Learnability (kemudahan sistem untuk dipelajari) } \\
\hline \multicolumn{5}{|c|}{$\begin{array}{l}\text { Tulisan teks yang digunakan pada tiap halaman } \\
\text { aplikasi MARBEL tersebut sangat mudah dan jelas } \\
\text { bagi anda }\end{array}$} \\
\hline 2 & $\begin{array}{l}\text { Menu-menu yang ada aplikasi MARBEL cukup mudah } \\
\text { untuk dipahami }\end{array}$ & & & \\
\hline 3 & $\begin{array}{l}\text { Gambar-gambar yang terdapat pada aplikasi MARBEL } \\
\text { kurang membantu memudahkan untuk dipelajari }\end{array}$ & & & \\
\hline \multicolumn{5}{|c|}{ Efficiency (hemat dalam waktu penggunaan sistem) } \\
\hline 4 & $\begin{array}{l}\text { Saat masuk aplikasi membutuhkan waktu yang relatif } \\
\text { singkat }\end{array}$ & & & \\
\hline 5 & $\begin{array}{l}\text { Setiap tombol menu yang anda klik dapat } \\
\text { menampilkan dengan cepat }\end{array}$ & & & \\
\hline 6 & $\begin{array}{l}\text { Saat anda ingin menutup aplikasi, harus melalui } \\
\text { konfirmasi user terlebih dahulu }\end{array}$ & & & \\
\hline \multicolumn{5}{|c|}{ Memorability (kemudahan sistem untuk diingat) } \\
\hline 7 & Aplikasi ini mengandung gambar yang menarik & & & \\
\hline 8 & $\begin{array}{l}\text { Efek suara pada aplikasi sangat jelas dan mudah di } \\
\text { pahami dan di ingat }\end{array}$ & & & \\
\hline 9 & $\begin{array}{l}\text { Animasi pada aplikasi ini kurang menarik dan sukar } \\
\text { diingat }\end{array}$ & & & \\
\hline \multicolumn{5}{|c|}{ Errors (kesalahan dari sistem) } \\
\hline 10 & $\begin{array}{l}\text { Semua tombol pada aplikasi MARBEL berfungsi } \\
\text { dengan baik }\end{array}$ & & & \\
\hline 11 & $\begin{array}{l}\text { Terdapat pesan yang jelas terhadap tombol apabila } \\
\text { terjadi kesalahan sistem }\end{array}$ & & & \\
\hline 12 & $\begin{array}{l}\text { Anda menemukan saat di klik menu tidak memberikan } \\
\text { respon apapun }\end{array}$ & & & \\
\hline \multicolumn{5}{|c|}{ Satisfaction (kepuasan pengguna dalam menggunakan sistem) } \\
\hline 13 & $\begin{array}{l}\text { Anda memberikan nilai bagus untuk aplikasi ini di } \\
\text { play store }\end{array}$ & & & \\
\hline 14 & $\begin{array}{l}\text { Aplikasi ini sangat membantu anda dalam berlatih } \\
\text { sholat } 5 \text { waktu }\end{array}$ & & & \\
\hline 15 & $\begin{array}{l}\text { Anda tidak ingin menggunakan aplikasi ini kembali } \\
\text { dan tidak akan memberitahukan aplikasi ini kepada } \\
\text { kawan anda }\end{array}$ & & & \\
\hline
\end{tabular}

Pengukuran kuesioner pada table 1 dengan pengetahuan anak usia 6-8 Tahun tentang sholat menggunakan seperangakat alat tes/kuesioner tentang object pengetahuan yang mau diukur, selanjutnya dilakukan penilaian dimana setiap jawaban benar masing-masing pertanyaan diberi nilai 1 dan jika salah diberi nilai 0 . Penilaian dilakukan dengan cara membandingkan jumlah skor jawaban dengan skor yang diharapkan (tertinggi) kemudian dilakukan $100 \%$ dan hasilnya berupa prosentasi dengan rumus yang digukanan sebagai berikut: 
INTENSIF, Vol.2 No.2 August 2018

ISSN: 2580-409X (Print) / 2549-6824 (Online)

Website: http://ojs.unpkediri.ac.id/index.php/intensif

$$
N=\frac{S p \quad \mathrm{x}}{S m} 100 \%
$$

Keterangan :

$\mathrm{N} \quad=$ Nilai Perilaku

Sp $\quad=$ Skor yang didapat

$\mathrm{Sm} \quad=$ Skor tertinggi maksimum

Selanjutnya prosentase jawaban diinterpretasikan dalam kalimat kualitatif dengan acuan sebagai berikut :

Baik : Nilai $=76-100 \%$

Cukup : Nilai $=56-75 \%$

Kurang : Nilai $=\leq 56 \%$

Skala dalam pengukuran pengetahuan anak usia 6-8 Tahun yakni skala ordinal atau sama dengan skala nominal, juga memungkinkan dilakukannya kalsifikasi. Perbedaannya adalah dalam ordinal juga menggunakan susunan posisi. Skala ordinal sangat berguna karena satu kelas lebih besar atau kurang dari kelas lainnya.

C. Metode Analisa Data

Analisa data merupakan bagian yang sangat penting untuk mencapai tujuan, dimana tujuan pokok penelitian adalah menjawab pertanyaan-pertanyaan dalam mengungkap fenomena [4]. Untuk mengetahui adanya pengaruh aplikasi MARBEL dengan pengetahuan anak usia 6-8 Tahun dianalisis dengan menggunakan uji korelasi Spearman Rank. Korelasi Spearman Rank digunakan untuk mencari hubungan atau untuk menguji signifikansi hipotesis asosiatif bila masing-masing variabel yang dihubungkan berbentuk Ordinal (Suharto: 2013). dengan bantuan program computer SPSS versi 20.0 pada taraf signifikasi 0,05 . Jika nilai $\rho \leq \alpha 0.05$ maka Ho ditolak sehingga ada hubungan atau pengaruh, dan jika $\rho \geq \alpha 0.05$ maka Ho diterima atau tidak ada hubungan atau tidak ada pengaruh, jika dapat dikategorikan dengan kriteria sebagai berikut:

$0,00-0,199$ : tingkat hubungan sangat rendah

0,20-0,399 : tingkat hubungan rendah

$0,40-0,599$ : tingkat hubungan sedang

$0,60-0,799$ : tingkat hubungan kuat

$0,80-1,000 \quad$ : tingkat hubungan sangat kuat 
INTENSIF, Vol.2 No.2 August 2018

ISSN: 2580-409X (Print) / 2549-6824 (Online)

Website: http://ojs.unpkediri.ac.id/index.php/intensif

\section{HASIL DAN PEMBAHASAN}

Berikut ini adalah hasil uji statistic menggunakan uji korelasi Spearman Rank. Korelasi Spearman Rank digunakan untuk mencari hubungan atau untuk menguji signifikansi hipotesis asosiatif.

Uji kolerasi dalam penelitian ini dilakukan untuk mengetahui hubungan antara variabel bebas dengan variabel terkait dan sebaliknya hubungan variabel $\mathrm{X}$ dan Y bersifat:

Positif, artinga jika X naik maka Y naik

Negatif, artinya jika X naik maka Y turun

Hasil uji kolerasi Speamen Rank adalah sebagai berikut:

Tabel 2. HASIL UJI KOLERASI SPEARMEN'S

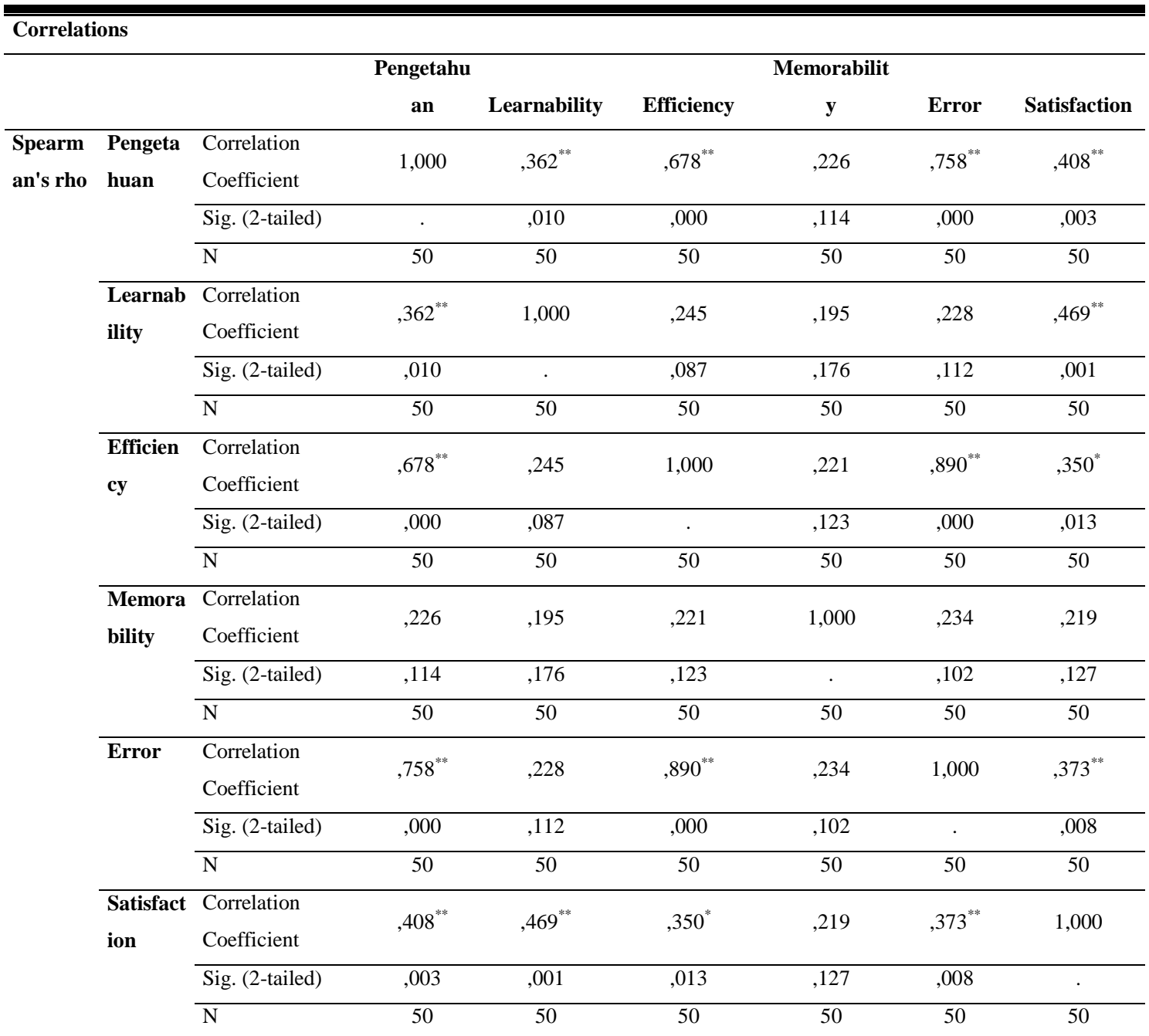

**. Correlation is significant at the 0.01 level (2-tailed).

*. Correlation is significant at the 0.05 level (2-tailed). 
INTENSIF, Vol.2 No.2 August 2018

ISSN: 2580-409X (Print) / 2549-6824 (Online)

Website: http://ojs.unpkediri.ac.id/index.php/intensif

Berdasarkan hasil dari pengujian tabel 2 dapat diartikan bahwa kolerasi antara pengetahuan dengan Learnability adalah 0,362, angka tersebut menunjukkan lemahnya hubungan antara pengetahuan dengan learnability karena nilai $r$ lebih tinggi dari 0,005 yang berarti tidak hubungan atau kolerasi antara learnability dengan pengetahuan anak. Kolerasi antara pengetahuan dengan efficiency adalah 0,678, angka tersebut menunjukkan tingginya hubungan antara pengetahuan dengan efficiency karena nilai $r$ lebih kecil dari 0,005 yang berarti bahwa ada hubungan atau kolerasi antara efficiency dengan pengetahuan anak.

Kolerasi dengan memorability dengan pengetahuan anak adalah 0.226 , angka tersebut menunjukan lemahnya hubungan antara memorability dengan pengetahuan anak karena nilai $r$ lebih besar dari 0,005 yang berarti tidak ada hubungan antara memorability dengan pengetahuan anak. Kolerasi dengan error dengan pengetahuan anak adalah 0.758, angka tersebut menunjukan tingginya hubungan antara error dengan pengetahuan anak karena nilai $r$ kecil dari 0,005 yang berarti ada hubungan antara error dengan pengetahuan anak. Kolerasi dengan satisfaction dengan pengetahuan anak adalah 0.408 , angka tersebut menunjukan tingginya hubungan antara satisfaction dengan pengetahuan anak karena nilai $r$ lebih kecil dari 0,005 yang berarti ada hubungan antara satisfaction dengan pengetahuan anak. Untuk lebih jelasnya dapat dilihat pada tabel 3:

Tabel 3. KESIMPULAN UJI KOLERASI

\begin{tabular}{clc}
\hline \hline No & \multicolumn{1}{c}{ Hipotesa } & Keterangan \\
\hline 1 & $\begin{array}{l}\text { Hubungan atau kolerasi antara learnability } \\
\text { dengan pengetahuan anak }\end{array}$ & Tidak terdapat hubungan \\
\hline 2 & $\begin{array}{l}\text { Hubungan atau kolerasi antara efficiency } \\
\text { dengan pengetahuan anak }\end{array}$ & Ada hubungan \\
\hline 3 & $\begin{array}{l}\text { Hubungan antara memorability dengan } \\
\text { pengetahuan anak }\end{array}$ & Tidak terdapat hubungan \\
\hline 4 & $\begin{array}{l}\text { Hubungan antara } \text { error dengan pengetahuan } \\
\text { anak }\end{array}$ & Ada hubungan \\
\hline 5 & $\begin{array}{l}\text { Hubungan antara satisfaction dengan } \\
\text { pengetahuan anak }\end{array}$
\end{tabular}


INTENSIF, Vol.2 No.2 August 2018

ISSN: 2580-409X (Print) / 2549-6824 (Online)

Website: http://ojs.unpkediri.ac.id/index.php/intensif

\section{KESIMPULAN DAN SARAN}

Hasil pembahasan yang telah dilakukan pada bab sebelumnya maka dapat disimpulkan sebagai berikut: (1) Ada pengaruh media pembelajaran Marbel huruf versi mobile berdasarkan human computer interaction (HCI) pada segi usability untuk variabel efficiency[8], error dan satisfaction terhadap tingkat pengetahuan anak usia 6-8 Tahun di Desa Semanding Kecamatan Kauman Kabupaten Ponorogo. (2) Tidak ada pengaruh media pembelajaran Marbel huruf versi mobile berdasarkan human computer interaction (HCI) pada segi usability untuk variabel learnability dan memorability tidak ada pengaruh terhadap tingkat pengetahuan anak usia 6-8 Tahun di Desa Semanding Kecamatan Kauman Kabupaten Ponorogo.

Berdasarkan hasil penelitian dan kesimpulan penelitian yang telah di uraikan sebelumnya, disampaikan beberapa saran sebagai berikut: (1) Perlunya pengembangan aplikasi dalam kemudahan pengunaan dan arti dari simbol yang ada dalam sistem dan penilaian dengan lebih banyak penilaian multi attribute [9] sehingga meningkatkan kualitas media pembelajaran Marbel huruf versi mobile, kualitas informasi dan kualitas layanan sehingga mempengaruhi penggunaan media pembelajaran Marbel versi mobile yang baik[10]. (2) Diperlukan dukungan orang tua anak dalam hal ini minat terhadap anak serta dukungan fasilitas berupa smartphone android dalam penerapan media pembelajaran Marbel huruf versi mobile.

\section{DAFTAR PUSTAKA}

[1] Sapto Haryoko, Efektifitas Pemanfaatan Media Audio Visual Sebagai Alternatif Optimalisasi Model Pembelajaran., Vol. 5 No. Jurnal Edukasi@Elektro, 2009.

[2] Sugiyono, Metode Penelitian Kunatitatif Kualitatif dan R\&D. Bandung: Alfabeta, 2008.

[3] J. P. \& W. N. . Frankel, How to Design and Evaluate Research in Education. New York: McGraw-Hill Companies, Inc, 2008.

[4] Nursalam, Konsep \& Penerapan Metodologi Penelitian Ilmu Keperawatan: Pedoman Skripsi, Tested an Instrumen Penelitian Keperawatan. Jakarta: Salemba Medika, 2003.

[5] Arikunto, Prosedur Penelitian Suatu Pendekatan Praktek. Jakarta: PT. Rineka Cipta, 2006. 
INTENSIF, Vol.2 No.2 August 2018

ISSN: 2580-409X (Print) / 2549-6824 (Online)

Website: http://ojs.unpkediri.ac.id/index.php/intensif

[6] Nursalam, Manajemen Keperawatan, 3rd ed. Jakarta: Salemba Medika.

[7] Sugiyono, Metode Penelitian Kuantitatif Kualitatif dan $R \& D$. Bandung: Alfabeta, 2007.

[8] Abda'u, P., Winarno, W., \& Henderi, H., Evaluasi Penerapan SIMRS Menggunakan Metode HOT-Fit di RSUD dr. Soedirman Kebumen. INTENSIF, 2(1), 46-56, 2018. doi:10.29407/intensif.v2i1.11817

[9] S. Sucipto, "Analisa Hasil Rekomendasi Pembimbing Menggunakan Multi-Attribute Dengan Metode Weighted Product ," Fountain Informatics J., vol. 2, no. 1, pp. 27-31, 2017.

[10] Kusuma, D., \& Shodiq, M. , Sistem Rekomendasi Destinasi Pariwisata Menggunakan Metode Hibrid Case Based Reasoning dan Location Based Service Sebagai Pemandu Wisatawan di Banyuwangi. INTENSIF, I(1), 28-34, 2017, doi:10.29407/intensif.v1i1.540 